Available online at

http://ojs.unik-kediri.ac.id/index.php/ukarst/index

\title{
Optimizing Flexural Strength of Concrete Fc' 14,5 MPa Using Acetylene Welding Carbide Waste
}

\author{
B. Damara $^{1 *}$, S. D. Hartantyo ${ }^{2}$ \\ ${ }^{1 * 2}$ Faculty of Engineering, Lamongan Islamic University. \\ Email: ${ }^{\text {* }}$ bobbydamara@unisla.ac.id
}

\section{A R T I C LE IN F O}

\section{Article History :}

Article entry : :26-08-2021

Article revised : 17-09-2021

Article received : 15-10-2021

\section{Keywords :}

Acetylene Welding Carbide

Waste, Concrete, Flexural

Strength, Hazardous Waste.

IEEE Style in citing this article : [21] W. Tjaronge, A. M. Akkas, and A. S. Ulvah, "Experimental study of concrete compressive strength using lightweight concrete debris waste as a substitute for coarse aggregate," Int. J. Innov. Technol. Explore. Eng., 2019

\begin{abstract}
A B S T R A C T
Replacing the main material using unused materials such as hazardous waste can be utilized in concrete innovation. One of the hazardous wastes that can utilize the waste generated from the acetylene welding process. The waste has hardening properties when exposed to water. Its properties are almost the same as cement can replace or add part of the cement mixture. Conducted this research was to determine the effect of using carbide waste from the acetylene welding process on the flexural strength of concrete. The experimental method is carried out by making test objects in the laboratory. The proportions of waste added were $7 \%, 10 \%$, and $12 \%$ by weight of cement. The test object used is in the form of a beam with dimensions of $60 \mathrm{~cm} \times 15 \mathrm{~cm} \times 15 \mathrm{~cm}$. The planned initial quality is concrete $\mathrm{F}^{\prime} \mathrm{c} 14.5 \mathrm{MPa}(\mathrm{K} 175)$. The flexural strength test was carried out at the age of 27 days of concrete. From the results of the research carried out, it is found that the use of carbide waste from the acetylene welding process has not been able to improve the quality of concrete significantly. The highest flexural strength was obtained from waste at $7 \%$, with a flexural strength value of $9.692 \mathrm{Mpa}$. So from these results, it can be used as a reference in the utilization of carbide waste from the acetylene welding process.
\end{abstract}

\section{Introduction}

Concrete is a material obtained from mixing fine AggregateAggregate (sand), coarse aggregate (coral/crushed stone), cement and water [1]. The use of concrete is a very dominant construction material. Concrete has advantages in manufacturing and ease of shape according to the desired structure, such as high-rise building work, roads, da, ms, and so on [2]. Following 
the development of the industrial revolution 5.0 the manufacture of concrete is very varied. It undergoes modifications from fly ash material, silica fume, sandblasting or waste, as a substitute for cement or AggregateAggregate.

Concrete work requires high accuracy. The use of the dominant concrete constituent materials derived from natural materials will make the material run out. Moreover, The monolithic nature of concrete cannot blend with old concrete and has a weak tensile strength be a weakness of concrete that needs to be considered. Concrete itself can be tested for several tests, namely compressive strength and flexural strength [3]. The flexural strength of concrete is the ability or property of the concrete beam tested on two supports to withstand the force perpendicular to the axis of the test object, which is given by the concrete block until the test object breaks [4]. The flexural strength of concrete is expressed in Mega Pascal (MPa) force per unit area. Although the concrete can accept the load force well, its strength when it receives the tensile force is quite low. The concrete can also experience cracks such as hair strands and structural cracks due to drastic temperature changes in a relatively short time. Due to the nature of the concrete that can bear a large compressive load, the concrete will be very vulnerable with minimum tensile forces. It must calculate the work in the manufacture in detail and precisely. There is a need for something innovative so that good quality concrete can accept vertical or horizontal loads. Horizontally well or perfectly [5][2].

Must develop alternative use of concrete building materials so that concrete, natural materials are not exhausted due to the use of concrete. As an alternative, it can be done to improve the quality of concrete. One of them is utilizing hazardous waste generated from the welding process that produces carbide residue or sludge from acetylene welding. The waste itself, which has properties resembling cement which can harden when exposed to water, allows it to be used as an alternative to cement in concrete mixtures [2][6].

Based on several studies that have been carried out, using B3 waste carbide dregs, a mixture of $5 \%$ is obtained; $10 \% ; 15 \%$; and $20 \%$ is $16.32 \mathrm{MPa} ; 17.81 \mathrm{MPa} ; 18.89 \mathrm{MPa}$; and 15.24 MPa can increase the compressive strength. Thus, we can say that carbide dregs affect the quality of concrete in terms of compressive strength[7][8]. However, there has been no research that describes carbide dregs waste on the flexural strength of concrete, so there is a need for in-depth research on the use of carbide dregs B3 waste which is reviewed on the flexural strength of concrete.

I conducted this research to know the effect of using hazardous waste from acetylene welding on the flexural strength of concrete, with mixed variations of $7 \%, 10 \%$, and $12 \%$ of B3 
waste that replaces Portland cement. So, it can know whether can use hazardous waste generated from the acetylene welding process to improve the quality of concrete in terms of bending strength.

\section{Research Method}

The research was carried out using an experimental method with the manufacture of test objects in the laboratory. Research refers to SNI and ASTM standards [9][6]. The test object in this study used a beam with dimensions of $60 \mathrm{~cm}$ x $15 \mathrm{~cm}$ x $15 \mathrm{~cm}$. The mix design used was the quality of concrete F'c $14,5 \mathrm{MPa}$ (K175)

\subsection{Material Research}

The materials used consist of fine AggregateAggregate, coarse AggregateAggregate, hazardous waste from acetylene welding, cement, and water with the following description:

1) Fine Aggregate

Fine AggregateAggregate for concrete is natural sand resulting from the natural disintegration of rocks. This AggregateAggregate measures $0.063 \mathrm{~mm}-4.76 \mathrm{~mm}$, which includes coarse sand and fine sand, In the concrete mixture, AggregateAggregate is a strengthening and filler material.

2) Coarse Aggregate

Coarse AggregateAggregate as a result of natural disintegration of rock or in the form of crushed stone obtained from the stone crushing industry, with grains measuring between $4.76 \mathrm{~mm}-150 \mathrm{~mm}$, Coarse AggregateAggregate must consist of hard and non-porous grains. Coarse AggregateAggregate with flat grains can only be used if the number of flat grains does not exceed $20 \%$ of the total weight of the AggregateAggregate, Coarse AggregateAggregate must not contain more than $1 \%$ silt in its dry weight. If it exceeds must be washed, the coarse AggregateAggregate must pass a hardness test with a Rudeloff test vessel with a test load of 20 tons, The fineness number for Coarse Aggregate is between $6-7.5$.

3) Hazardous waste

Hazardous Carbide waste is the result of a welding process that utilizes carbide gas (acetylene gas $=\mathrm{C} 2 \mathrm{H} 2$ ) as welding fuel[10][11][12]. The use of carbide mixed with water can cause a chemical reaction that becomes gas and a welding process occurs which is used to connect one iron to another due to the chemical reaction process mixes carbide and water there is hazardous waste in the form of fine dregs from acyethylene gas[10][6]. 


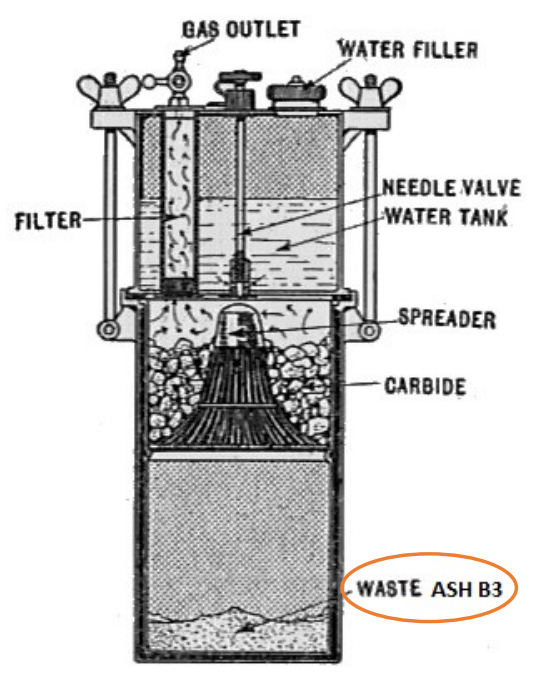

Source : Laboratory Research Results, 2021

Figure 1. Acetylene Welding Generator

4) Hydraulic binder with cement composition :
a. $7 \%$ Acetylene welding carbide waste and $93 \%$ cement
b. $10 \%$ Acetylene welding carbide waste and $90 \%$ cement
c. $12 \%$ Acetylene welding carbide waste and $88 \%$ cement

\subsection{Materials Testing}

Testing of concrete stacking materials is carried out so that the materials used meet the standards and meet the requirements as concrete stacking materials.

\section{1) Cement Testing}

Testing of cement material is carried out using two tests, namely as follows :

a. Portland cement normal consistency test

The normal consistency of cement is greatly influenced by the amount of water used by the cement. Normal consistency is achieved when the vikat needle can penetrate the paste $10 \pm 1$ within 30 seconds of being released[13][14].

b. Cement bonding and hardening time test

Bonding Time Cement after mixing with water will experience binding, and after binding then hardens. The duration of binding is highly dependent on the composition of the compounds in the cement and the temperature of the surrounding air. There are 2 (two) kinds of binding time on cement paste, namely the initial setting time and the final setting time. Testing the binding and hardening time of cement[13][14]. 


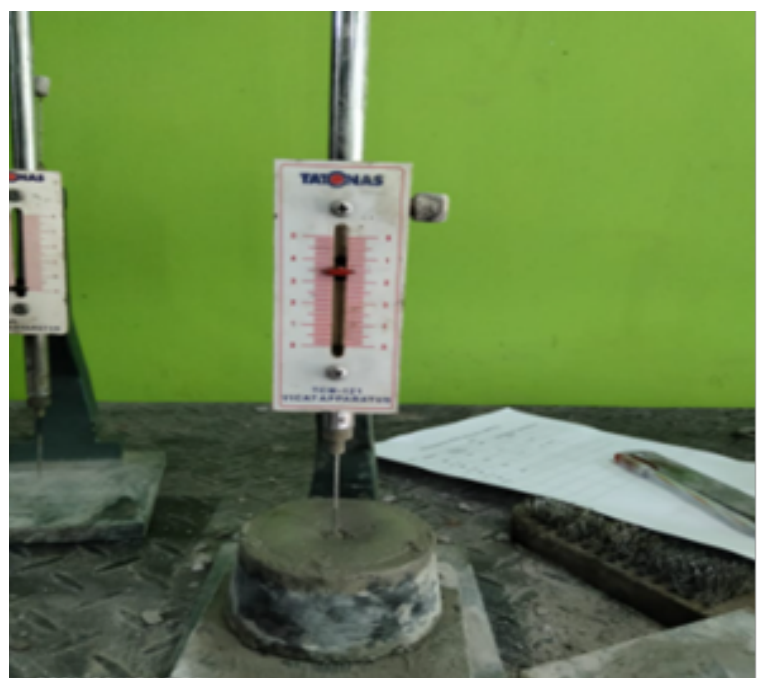

Source : Laboratory Research Results, 2021

Figure 2. Vicat tool

2) Hazardous Waste Material Testing

The testing of the carbide waste material is carried out by testing filter analysis, grading distribution of hazardous waste and testing the bonding time and hardening of cement with hazardous waste substitutes[6][7][10].

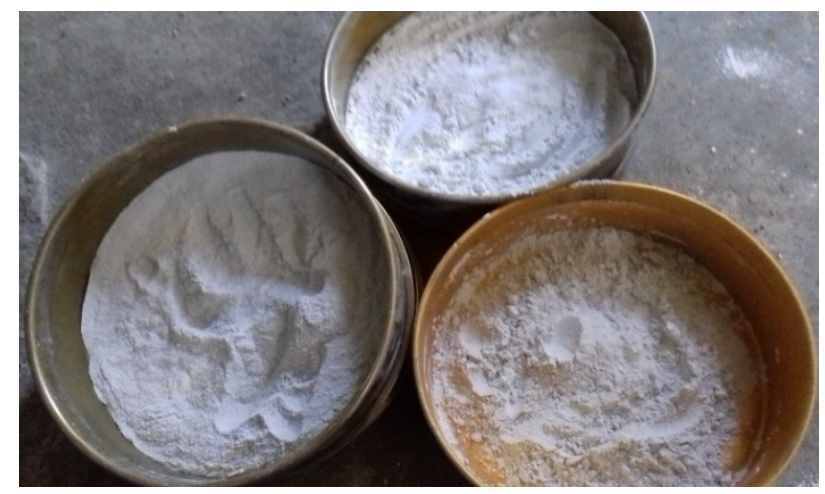

Source : Laboratory Research Results, 2021

Figure 3. Hazardous Waste Ash from Carbide Dregs Passing 200 (0.075mm) sieve.

\subsection{Fresh Concrete Testing}

Fresh concrete testing is a slump test carried out 3 times and the average is taken for each sample with a planned slump value of $12 \pm 2 \mathrm{~cm}$, the percentage of research to know the viscosity properties of fresh concrete[15].

\section{$2.4 \quad$ Flexural Strength}

Hard concrete testing in this study was carried out using concrete blocks with dimensions of $60 \mathrm{~cm} \times 15 \mathrm{~cm} \times 15 \mathrm{~cm}$ [15], Flexural strength is the property of a concrete beam 
That is placed on two supports and withstands the force in a direction perpendicular to the axis of the test object given to the concrete beam[16][17][18], until the test object breaks and is expressed in Mega Pascal (MPa) force per unit area. The loading point of the concrete flexural strength test is a point (one or two points depending on the loading system used) with a certain distance as a concrete footing to be given the load. Based on SNI[7][19], there are 2 methods of flexural strength test in its implementation, namely Two-point loading system [20] and Single point loading system [8] The test object used must meet the provisions on the method of making and maintaining concrete test objects in the laboratory[21][16].

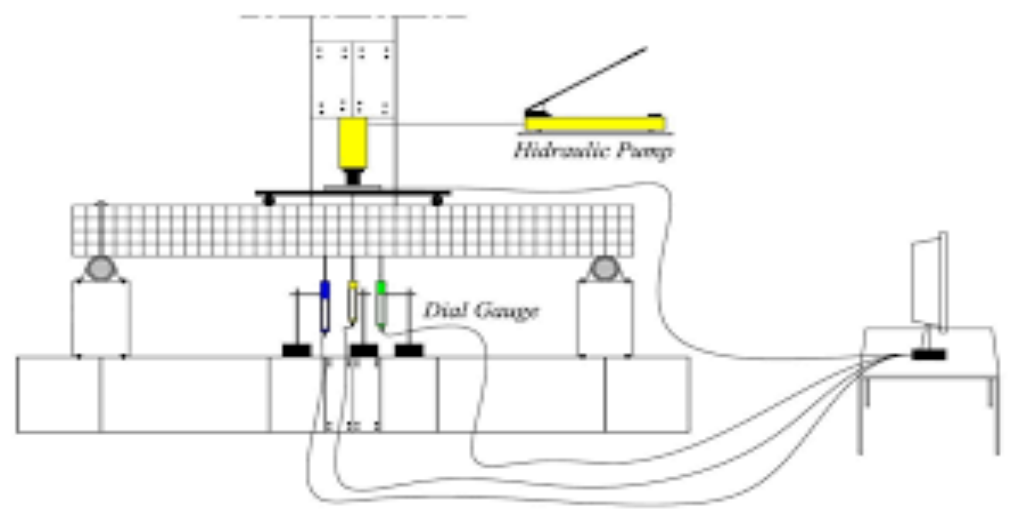

Source : Laboratory Research Results, 2021

Figure 4. Loading System Type

There are several formulas used in calculating the flexural strength of a beam[22][23], which are as follows :

1) The fracture of the test object is at $1 / 3$ the distance from the point of placement on the tensile part of the concrete[20][24][25], then the flexural strength is calculated according to the equation :

$f_{l t}=\frac{P L}{b h^{2}}$

2) If as a result of the test specimen fractures outside the center (outside $1 / 3$ of the distance from the point of placement) in the tensile section of the concrete, and the distance between the fracture point and the center of the load) is less than $5 \%$ of the distance from the point of placement[15][25][20]. The formula calculates the flexural strength of the concrete:

$f_{l t}=\frac{3 P c}{b h^{2}}$

\section{Results and Discussion}

The results of the research on the addition of hazardous waste carbide dregs, which are reviewed on the flexural strength of concrete obtained research data, including test results with 
the following description :

\subsection{Mix Design}

Concrete mix design is a mixture of concrete material compositions that have been determined with a design quality value, in this study using a F'c 14.5 MPa (K175) quality mix design. The following is a mixture of concrete compositions that use carbide waste as a substitute for cement:

Table 1. Mix Design

\begin{tabular}{lccccc}
\hline \multicolumn{1}{c}{ Material } & Unit & $0 \%$ & $7 \%$ & $10 \%$ & $12 \%$ \\
\hline Portland Cement & $\mathrm{kg}$ & 326 & 12.279 & 11.883 & 11.619 \\
\hline Fine Aggregate & $\mathrm{kg}$ & 760 & 760 & 760 & 760 \\
\hline Coarse Aggregate & $\mathrm{kg}$ & 1029 & 1029 & 1029 & 1029 \\
\hline Water & $\mathrm{kg}$ & 215 & 215 & 215 & 215 \\
\hline carbide dregs & $\mathrm{kg}$ & - & 0.924 & 1.320 & 1.584 \\
\hline
\end{tabular}

Source : Laboratory Research Results, 2021

In the table above, the proportions of each concrete constituent material requirement for variations in the use of carbide waste are $0 \%, 7 \%, 10 \%$ and $12 \%$.

\subsection{Materials Testing}

The material testing results outlined include cement testing and carbide waste testing with the following description:

\section{1) Cement Testing}

Three tests of Portland cement material were carried out 3 tests, namely, testing of normal cement consistency, binding time, and cement hardening. The following are the results of laboratory tests that have been carried out following SNI-15-0129-2004 :

Table 2. Normal Consistency of Portland Cement

\begin{tabular}{lccc}
\hline \multicolumn{1}{c}{ Trial Number } & 1 & 2 & 3 \\
\hline Cement Weight $\left(\mathrm{W}_{1}\right)$ & 250 gram & 250 gram & 250 gram \\
\hline Water Weight $\left(\mathrm{W}_{2}\right)$ & $70 \mathrm{cc}$ & $80 \mathrm{cc}$ & $90 \mathrm{cc}$ \\
\hline Penetration & 11 & 19 & 25 \\
\hline Consistency & $28 \%$ & $32 \%$ & $36 \%$ \\
$\frac{W_{2}}{W_{1}} \times 100 \%$ & & & \\
\hline
\end{tabular}

Source : Laboratory Research Results, 2021 
The normal cement consistency test was carried out 3 times, namely with a cement weight of 250 grams and a different water composition to obtain normal cement consistency test results

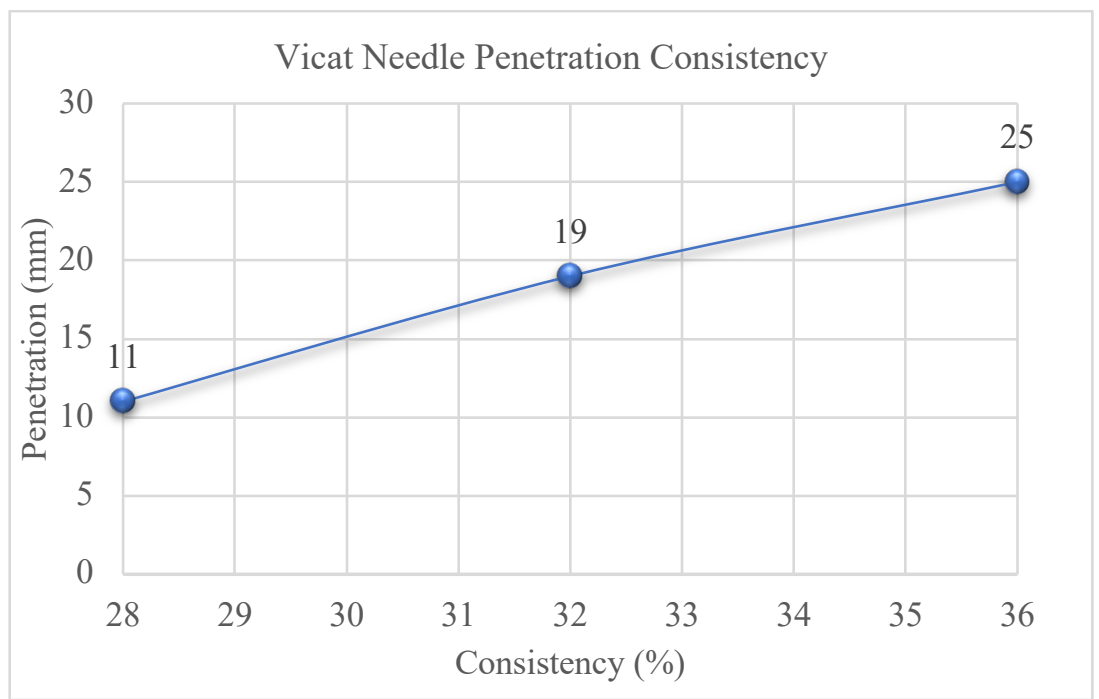

Source : Laboratory Research Results, 2021

Figure 5. Vicat Needle Penetration Consistency

From the results of the normal consistency test of cement referring to Table 2 and Figure 5, the wetness of the cement paste is $28 \%$ with a water weight of $70 \mathrm{cc}$. Following ASTM C-187-86 Normal Consistency of Hydraulic Cement, the consistency of cement is $26 \%-29 \%$. Testing of cement binding and hardening time was carried out in the initial 45 minutes with a penetration of $42.86 \mathrm{~mm}$ and ended at $0 \mathrm{~mm}$ penetration at 195 minutes.

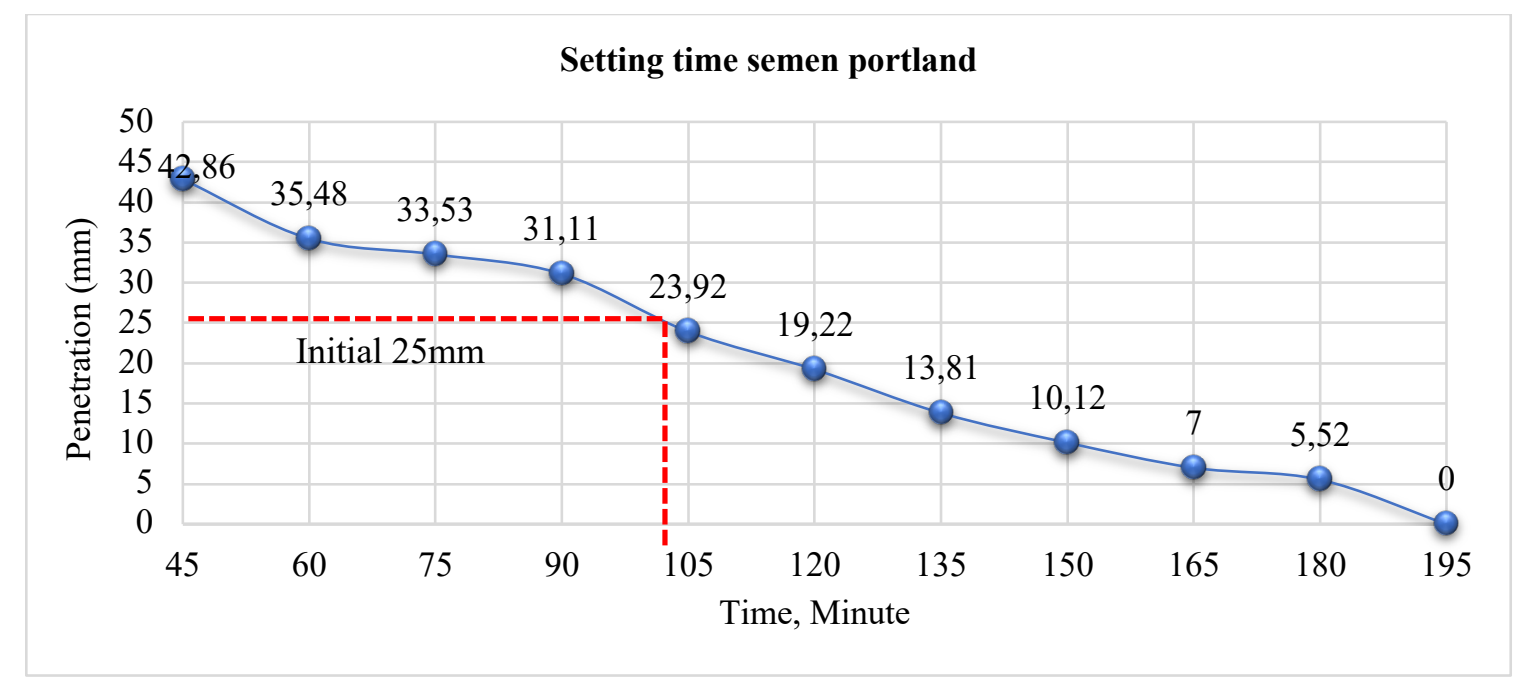

Source : Laboratory Research Results, 2021

Figure 6. Graph of Setting Time for Initial and Final 
Referring to Figure 6. In testing the bonding time and hardening of cement, obtained the results at 195 minutes. The penetration of the vicat needle was $0 \mathrm{~mm}$. The cement binding time occurred at 90-105 minutes reaching into the vicat needle $25 \mathrm{~mm}$.

\section{2) Hazardous waste testing}

Waste testing is carried out by testing sieve analysis and cement binding time with the results of laboratory tests as follows :

Table 3. Analysis of Hazardous Waste Filter

\begin{tabular}{ccccc}
\hline \multicolumn{2}{c}{ Sieve } & \multicolumn{2}{c}{ Left behind in the Sieve } & \multirow{2}{*}{ \% Cumulative Hold } \\
\cline { 1 - 3 } Number & Mm & Gram & 0 & 0 \\
\hline 4 & 4,76 & 0 & 0 & 0 \\
\hline 8 & 2,38 & 0 & 0 & 0 \\
\hline 30 & 0,59 & 0 & 44 & 44 \\
\hline 50 & 0,297 & 443 & 32 & 76 \\
\hline 100 & 0,149 & 316 & 17 & 94 \\
\hline 200 & 0,0745 & 174 & 6 & 100 \\
\hline Pan & 0 & 64 & 100 & 370,5 \\
\hline
\end{tabular}

Source : Laboratory Research Results, 2021

In table 3, the filter analysis results on hazardous waste dregs are obtained and the material used in this study is hazardous waste ash which passed the 200 filters.

Table 4. Testing of Cement Paste plus hazardous waste

\begin{tabular}{ccccc}
\hline \multirow{2}{*}{ Number } & Dropping Time & \multicolumn{3}{c}{ Penetration ( mm ) } \\
\cline { 2 - 5 } & (Minute) & $7 \%$ & $10 \%$ & $12 \%$ \\
\hline 1 & 45 & 42 & 42 & 43 \\
\hline 2 & 60 & 37 & 40 & 40 \\
\hline 3 & 75 & 35 & 38 & 38 \\
\hline 4 & 90 & 28 & 33 & 36 \\
\hline 5 & 105 & 24 & 29 & 31 \\
\hline 6 & 120 & 19 & 24 & 28 \\
\hline 7 & 135 & 14 & 19 & 22 \\
\hline 8 & 150 & 9 & 14 & 17 \\
\hline 9 & 165 & 7 & 9 & 10 \\
\hline 10 & 180 & 3 & 5 & 5 \\
\hline 11 & 195 & 1 & 2 & 3 \\
\hline 12 & 210 & 0 & 0 & 1 \\
\hline 13 & 225 & - & - & 0 \\
\hline
\end{tabular}

Source : Laboratory Research Results, 2021

The results of testing the binding and hardening time of cement added with hazardous waste carbide dregs obtained results in the initial 45 minutes the percentage of $7 \%$ penetration Optimizing Flexural Strength of Concrete Fc' 14,5 MPa Using Acetylene Welding Carbide Waste 
$42 \mathrm{~mm}, 10 \%$ penetration $42 \mathrm{~mm}$ and $12 \%$ penetration $43 \mathrm{~mm}$ and hardening time at a percentage of $7 \%$ at 210 minutes, percentage $10 \% \min 210$ and the percentage of $12 \%$ mixture at minute 225 decreased $0 \mathrm{~mm}$.

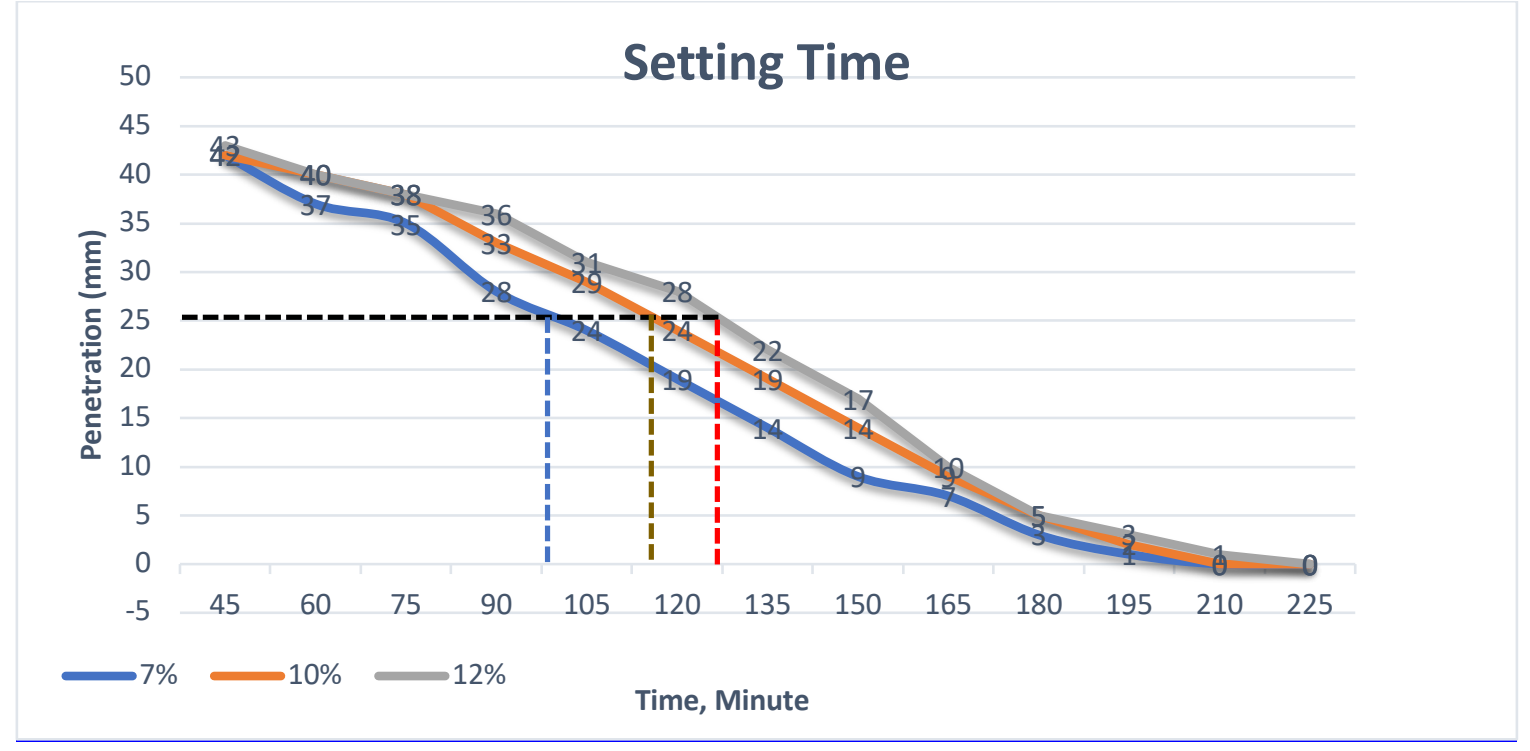

\section{Source : Laboratory Research Results, 2021}

Figure 7. Testing of Cement Paste plus hazardous waste

From the laboratory tests results, the bonding and hardening time of cement that have been replaced by B3 waste are according to the percentage of $7 \%$ of hardening time of 210 minutes, $10 \%$ of hardening time of 210 minutes and $12 \%$ of 225 minutes.

\subsection{Slump Test}

Slump testing is carried out to find out how the viscosity of fresh concrete is shown by slump testing. Based on the results of laboratory tests, the slump value of fresh concrete is obtained as follows :

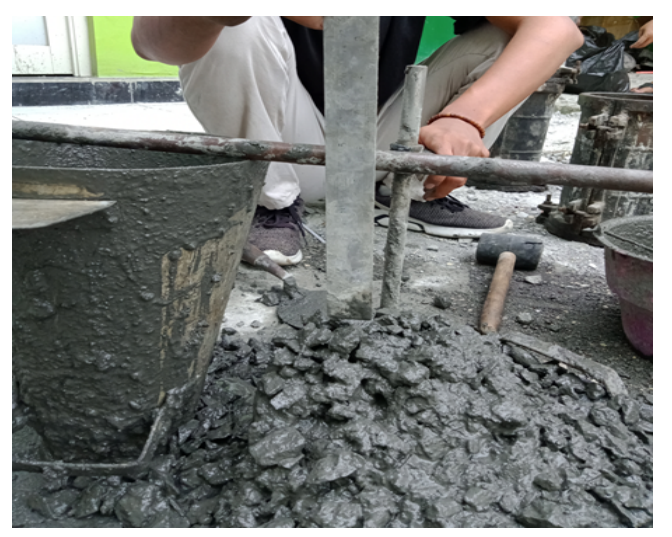

Source : Laboratory Research Results, 2021

Figure 8. Slump Test 


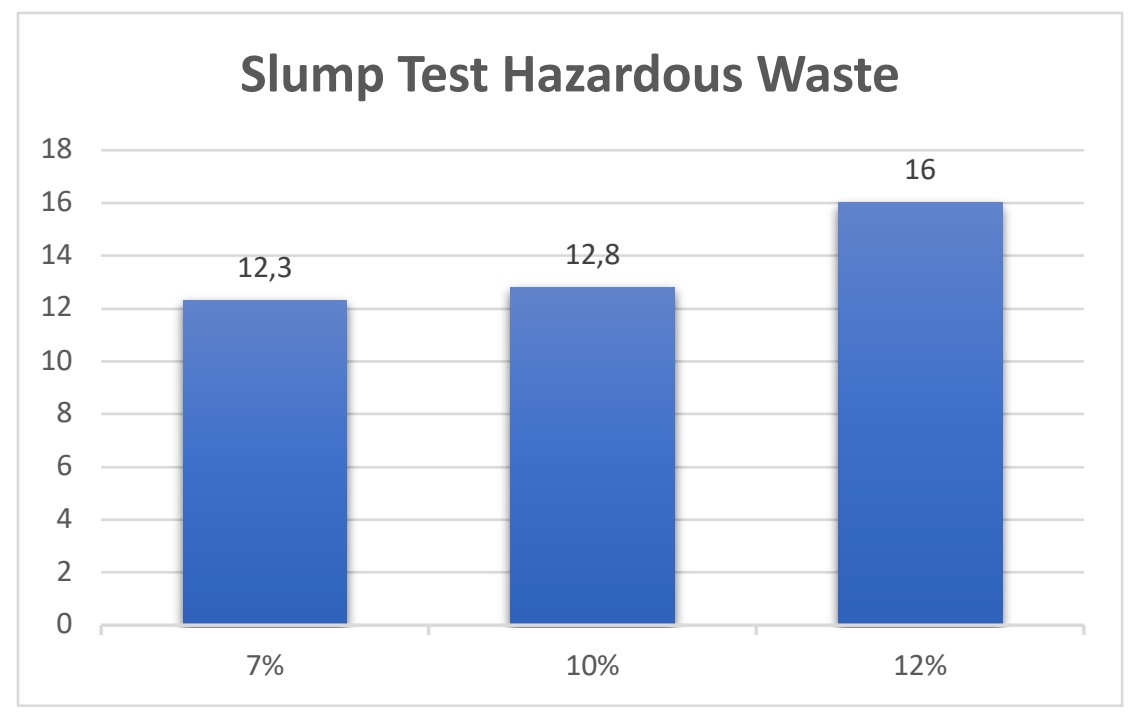

Source : Laboratory Research Results, 2021

Figure 9. Results of Slump Value Using Hazardous Waste

From the results of the slump tests carried out, the results of slump percentage are $7 \%$ $12.3 \mathrm{~cm}$, the percentage is $10 \% 12.8 \mathrm{~cm}$ and $12 \% 16 \mathrm{~cm}$, this shows that the slump value is in accordance with the plan.

\subsection{Flexural Strength Test Results}

Based on the results of testing the flexural strength of concrete with reference to SNI $03-1947-1990$ the procedure for testing the flexural strength of concrete is carried out on each variation with the loading being at $1 / 3$ middle span, with the results of research on the flexural strength of concrete as follows :

Table 5. Flexural Strength variation $7 \%$

\begin{tabular}{lccc}
\hline Test Item Number & $\mathbf{1}$ & $\mathbf{2}$ & $\mathbf{3}$ \\
\hline Volume Weight $\left(\mathrm{kg} / \mathrm{m}^{3}\right)$ & 2281,48 & 2274,07 & 2277,78 \\
\hline Maximum Load $(\mathrm{N})$ & 196133 & 171616 & 191230 \\
\hline Cross Section Distance $=\mathrm{a}(\mathrm{mm})$ & 210 & 195 & 220 \\
\hline Cross View Width $=\mathrm{b}(\mathrm{mm})$ & 175 & 150 & 160 \\
\hline Latitude Visible Height $=\mathrm{h}(\mathrm{mm})$ & 160 & 165 & 150 \\
\hline Test Bending Strength $(\mathrm{MPa})$ & 9,194 & 8,195 & 11,686 \\
\hline Average Flexural Strength $(\mathrm{MPa})$ & & 9,692 & \\
\hline
\end{tabular}

Source : Laboratory Research Results, 2021

Table 5 tested the results of testing concrete blocks with a percentage of $7 \%$ as many as 3 test objects obtained an average flexural strength of $9.692 \mathrm{Mpa}$. 
Table 6. Flexural Strength variation $10 \%$

\begin{tabular}{lccc}
\hline Test Item Number & $\mathbf{1}$ & $\mathbf{2}$ & $\mathbf{3}$ \\
\hline Volume Weight $\left(\mathrm{kg} / \mathrm{m}^{3}\right)$ & 2325,93 & 2385,19 & 2451,85 \\
\hline Maximum Load $(\mathrm{N})$ & 171616,4 & 142196,4 & 156906,4 \\
\hline Cross Section Distance $=\mathrm{a}(\mathrm{mm})$ & 230 & 240 & 240 \\
\hline Cross View Width $=\mathrm{b}(\mathrm{mm})$ & 170 & 175 & 155 \\
\hline Latitude Visible Height $=\mathrm{h}(\mathrm{mm})$ & 160 & 160 & 160 \\
\hline Test Bending Strength $(\mathrm{MPa})$ & 9,07 & 7,618 & 9,49 \\
\hline Average Flexural Strength $(\mathrm{MPa})$ & & 8,726 &
\end{tabular}

Source : Laboratory Research Results, 2021

Table 6 tested the results of testing concrete blocks with a percentage of $10 \%$ as many as 3 test objects obtained an average flexural strength of $8.726 \mathrm{Mpa}$.

Table 7. Flexural Strength variation $12 \%$

\begin{tabular}{lccc}
\hline Test Item Number & $\mathbf{1}$ & $\mathbf{2}$ & $\mathbf{3}$ \\
\hline Volume Weight $\left(\mathrm{kg} / \mathrm{m}^{3}\right)$ & 2272,59 & 2380 & 2316,3 \\
\hline Maximum Load $(\mathrm{N})$ & 132389,8 & 137293,1 & 152003,1 \\
\hline Cross Section Distance $=\mathrm{a}(\mathrm{mm})$ & 215 & 210 & 235 \\
\hline Cross View Width $=\mathrm{b}(\mathrm{mm})$ & 160 & 155 & 155 \\
\hline Latitude Visible Height $=\mathrm{h}(\mathrm{mm})$ & 175 & 160 & 170 \\
\hline Test Bending Strength $(\mathrm{MPa})$ & 5,809 & 7,266 & 7,974 \\
\hline Average Flexural Strength $(\mathrm{MPa})$ & & 7,016 &
\end{tabular}

Source : Laboratory Research Results, 2021

Table 7 tested the results of testing concrete blocks with a percentage of $12 \%$ as many as 3 test objects obtained an average flexural strength of 7,016 Mpa. 


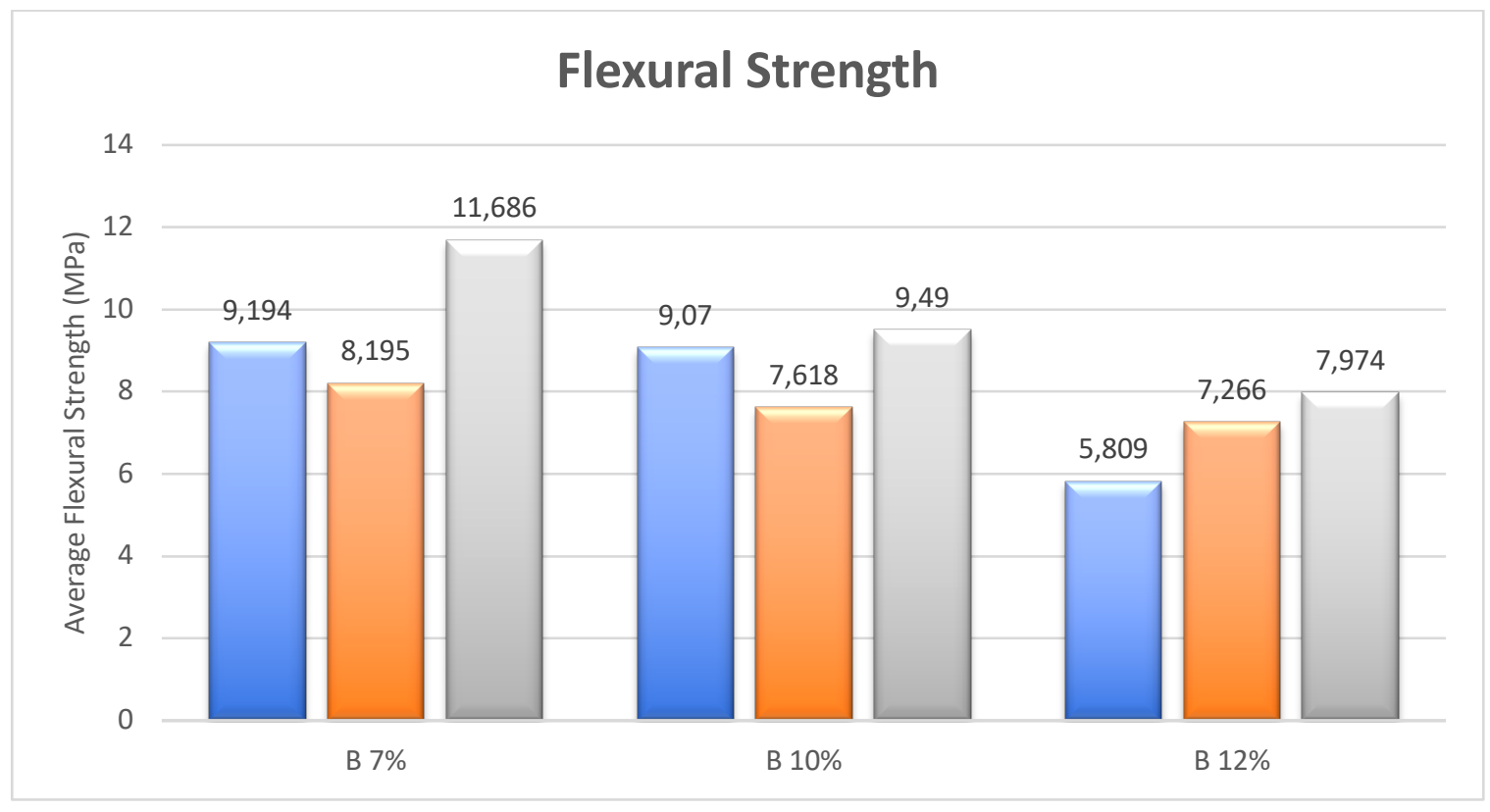

Source : Laboratory Research Results, 2021

Picture 10. Flexural Strength Test Results Using Hazardous Waste

From the results of testing the flexural strength of concrete with a percentage of $7 \%$, $10 \%$ and $12 \%$ the use of $\mathrm{B} 3$ waste carbide dregs as a substitute for cement obtained an average value of the best flexural strength of $9.692 \mathrm{Mpa}$ at a percentage of $7 \%$ and the increasing percentage of the use of B3 waste carbide dregs also decreases. flexural strength of the concrete beam test object.

\section{Conclusion}

The conclusion from the results of the study of adding hazardous waste to the concrete block test object is as follows :

1. The more additions of hazardous waste the less the value of the flexural strength of the concrete beams shown in the mixture, the percentage of $12 \%$ of hazardous waste has an average value of $7.016 \mathrm{Mpa}$.

2. The best mixture in the study of adding hazardous waste obtained a flexural strength value of $9.692 \mathrm{Mpa}$ at a percentage mixture of $7 \%$. 


\section{Reference}

[1] S. Abhyankar and M. Chouragade, "Environmental Aspects of Concrete and Use of Waste Glass," HELIX, 2020.

[2] L. F. Aprida, D. Dermawan, and R. Bayuaji, "Identifikasi Potensi Pemanfaatan Limbah Karbit dan Abu Sekam Padi sebagai Bahan Alternatif Pengganti Semen," Conf. Proceeding Waste Treat. Technol., 2015.

[3] M. F. Akhter, F. Azam, and D. A. Hussain, "Comparative Study on Effect of Fly Ash and Rice Husk Ash on Strength of Concrete," Int. J. Trend Sci. Res. Dev., 2018.

[4] O. D. Atoyebi and O. M. Sadiq, "Experimental data on flexural strength of reinforced concrete elements with waste glass particles as partial replacement for fine aggregate," Data Br., 2018.

[5] D. Bisikirske, D. Blumberga, S. Vasarevicius, and G. Skripkiunas, "Multicriteria analysis of glass waste application," Environ. Clim. Technol., 2019.

[6] B. Damara and Z. Lubis, "Pengaruh Penambahan Limbah B3 Pada Kuat Beton Mutu K175," J. CIVILA, vol. 3, no. 1, p. 100, 2018.

[7] D. Dermawan and M. L. Ashari, "Studi Komparasi Kelayakan Teknis dan Lingkungan Pemanfaatan Limbah B3 Sandblasting terhadap Limbah B3 Sandblasting dan Fly Ash sebagai Campuran Beton,” J. Presipitasi Media Komun. dan Pengemb. Tek. Lingkung., 2018.

[8] S. Praveenkumar and G. Sankarasubramanian, "Behavior of high performance fibre reinforced concrete composite beams in flexure," Rev. Rom. Mater. Rom. J. Mater., 2019.

[9] R. Žurauskiene and M. Valentukevičiene, "Experimental research on quality parameters of recycled concrete," Materials (Basel)., 2020.

[10] N. R. Dewi, D. Dermawan, and M. L. Ashari, "STUDI PEMANFAATAN LIMBAH B3 KARBIT DAN FLY ASH SEBAGAI BAHAN CAMPURAN BETON SIAP PAKAI (BSP) (STUDI KASUS : PT. VARIA USAHA BETON)," J. Presipitasi Media Komun. dan Pengemb. Tek. Lingkung., 2016.

[11] M. Rezania, M. Panahandeh, S. M. J. Razavi, and F. Berto, "Experimental study of the simultaneous effect of nano-silica and nano-carbon black on permeability and mechanical properties of the concrete," Theor. Appl. Fract. Mech., 2019. 
[12] M. Saberian, J. Li, S. T. A. M. Perera, G. Ren, R. Roychand, and H. Tokhi, “An experimental study on the shear behaviour of recycled concrete aggregate incorporating recycled tyre waste," Constr. Build. Mater., 2020.

[13] A. T. Gebremariam, F. Di Maio, A. Vahidi, and P. Rem, "Innovative technologies for recycling End-of-Life concrete waste in the built environment," Resour. Conserv. Recycl., 2020.

[14] J. Mansoor et al., "Analysis of mechanical properties of self compacted concrete by partial replacement of cement with industrial wastes under elevated temperature," Appl. Sci., 2018.

[15] M. N. N. Khan, A. K. Saha, and P. K. Sarker, "Reuse of waste glass as a supplementary binder and aggregate for sustainable cement-based construction materials: A review," Journal of Building Engineering. 2020.

[16] L. Gyura, M. Gáspár, and A. Balogh, "Investigation of Thermal Effects of Flame Straightening on High-Strength Steels," in Lecture Notes in Mechanical Engineering, 2021.

[17] B. S. Saini and S. P. Singh, "Flexural fatigue life analysis of self compacting concrete containing 100\% coarse recycled concrete aggregates," Constr. Build. Mater., 2020.

[18] M. D. Sebayang, "Analyze the proportion of volcanic ash of Sinabung volcano at the most optimum to get the compressive strength and tensile strength of concrete," in IOP Conference Series: Materials Science and Engineering, 2020.

[19] N. Tamanna, R. Tuladhar, and N. Sivakugan, "Performance of recycled waste glass sand as partial replacement of sand in concrete," Constr. Build. Mater., 2020.

[20] V. G. Kalpana and K. Subramanian, "Behavior of concrete beams reinforced with GFRP BARS,” J. Reinf. Plast. Compos., 2011.

[21] W. Tjaronge, A. M. Akkas, and A. S. Ulvah, "Experimental study of concrete compressive strength using lightweight concrete debris waste as a substitute for coarse aggregate," Int. J. Innov. Technol. Explor. Eng., 2019.

[22] I. Török, A. Puskás, and J. Virág, "Post-tensioned Flat Slabs with Unbonded Tendons for Public Buildings,” in Procedia Manufacturing, 2019.

[23] M. U. Hossain, R. Cai, S. T. Ng, D. Xuan, and H. Ye, "Sustainable natural pozzolana concrete - A comparative study on its environmental performance against concretes with other industrial by-products," Constr. Build. Mater., 2021. 
[24] C. Irawan, R. Djamaluddin, I. G. P. Raka, Faimun, P. Suprobo, and Gambiro, "The effect of the presence of infilling concrete on flexural performance of spun pile - An experimental study," J. Teknol., 2020.

[25] S. Jesus, C. M. Pederneiras, C. B. Farinha, J. de Brito, and R. Veiga, "Reduction of the cement content by incorporation of fine recycled aggregates from construction and demolition waste in rendering mortars," Infrastructures, 2021. 